\title{
First record of an indoor pest sawtoothed grain beetle Oryzaephilus surinamensis (Coleoptera: Silvanidae) from wild outdoor wood ant nest
}

\author{
Jouni Sorvari, Salla K. Härkönen, Eero J. Vesterinen
}

Sorvari, J., Härkönen, S. K. \& Vesterinen, E. J. 2012: First record of an indoor pest sawtoothed grain beetle Oryzaephilus surinamensis (Coleoptera: Silvanidae) from wild outdoor wood ant nest. - Entomol. Fenn. 23: 69-71.

Alive individual adult sawtoothed grain beetle Oryzaephilus surinamensis (Linnaeus, 1758) was discovered inside a nest mound of the red wood ant Formica rufa Linnaeus, 1758 during a survey of myrmecophilous invertebrates. The sawtoothed grain beetle is a widespread indoor pest that has not previously been found in an ant nest. It is one of the most common pests in stored grain and cereal products, but the natural life-style of the species is not known. As the site of discovery was exceptional, we verified the species identification using the DNA barcode. If the sawtoothed grain beetle can live in mounds of red wood ants, the mounds may become widespread source habitats for the future infestations of this serious stored product pest.

J. Sorvari, S. K. Härkönen, E. J. Vesterinen, Department of Biology, Section of Ecology, FI-20014, University of Turku, Finland. J. Sorvari's present address: Department of Environmental Science, University of Eastern Finland, P.O. Box 1627, FI-70211 Kuopio, Finland (corresponding author: jouni.sorvari@uef.fi)

Received 5 March 2012, accepted 18 May 2012

\section{Introduction}

The sawtoothed grain beetle Oryzaephilus surinamensis (Linnaeus, 1758) along with the merchants grain beetle $O$. mercator (Fauvel, 1889) are among the most common pests in stored grain and cereal products, but their natural life-styles are not known. They currently have worldwide distributions, but they probably have a tropical origin with closely related species in Africa $(O$. parallelus Halstead, 1980) and Middle East (O. abeillei (Guillebeau, 1890) (Halstead 1980). They have not been documented to live outdoors in northern Europe, but $O$. surinamensis has sometimes been caught from light traps and beneath the bark of trees in Britain (Halstead 1980, Robinson 2005).
Oryzaephilus surinamensis has wide tolerance of humidity (between $10-90 \% \mathrm{RH}$ ) and it is relatively cold hardy, but it fails to complete its development under the temperature of $17{ }^{\circ} \mathrm{C}$ (Halstead 1980, Robinson 2005). The optimum temperature for development is between 30 and $35^{\circ} \mathrm{C}$ (Halstead 1980).

A wood ant (Formica rufa group) nest can maintain a constant temperature of $26-30{ }^{\circ} \mathrm{C}$ in summer and the deeper parts of the nest mound stay above the freezing point in winter (around $+5^{\circ} \mathrm{C}$; Rosengren et al. 1987, Sorvari \& Hakkarainen 2009). Thus, in a wood ant mound, the abiotic conditions for $O$. surinamensis would be close to optimal during summer and could be one of the best outdoor environments for overwintering in the boreal zone. 
Wood ant nest mounds would appear to be unlikely suitable habitats for most arthropods, because the ants are predaceous and aggressive towards nest intruders. However, wood ant nests have been proven to be hot spots for arthropod fauna (Laakso \& Setälä 1998). So far at least 166 coleopteran species are found in the nests of wood ants of Formica rufa group (Päivinen et al. 2002). In order to investigate the diversity of the wood ant-associated arthropods on Ruissalo Island (SW-Finland) we (SH, JS) conducted a field study where we sampled 12 nest mounds of Formica polyctena and 4 of $F$. rufa.

One of the $F$. rufa nests contained an alive adult $O$. surinamensis (Linnaeus, 1758) female (Fig. 1.), collected 3.VII.2009, Turku, Ruissalo, Finland $\left(60.4154^{\circ} \mathrm{N}, 22.1140^{\circ} \mathrm{E}\right), 9 \mathrm{~m}$ a.s.l.

\section{Site of discovery and sampling methods}

The F. rufa nest was located in a nature conservation area in the Kuuva region close to the southern tip of the Ruissalo Island. The habitat was dominated by Scots pine (Pinus sylvestris), mixed with birch (Betula pendula) and Norway spruce (Picea abies), in that order. The nest mound was $120 \mathrm{~cm}$ in diameter and the height was $55 \mathrm{~cm}$, which gives the nest mound a volume of 4221 when calculated with the formula of a half ellipsoid. The nest mound situated $300 \mathrm{~m}$ away from the nearest summer cottage and $530 \mathrm{~m}$ from the nearest permanently inhabited house. The distance to the nearest major grain storage was $7.7 \mathrm{~km}$.

Of the nest mound material, $0.9 \%$ (3.75 1) was examined. Five sub-samples of 0.751 , collected from the four cardinal points of the outer part of the active nest mound and one sub-sample from the top of the mound. The samples were taken about 3-5 $\mathrm{cm}$ beneath the outer layer of the mound. The sub-samples were pooled and sieved in the field with sieves of $2.5 \mathrm{~mm}$ and $1 \mathrm{~mm}$. The cruder material that did not go through the $1 \mathrm{~mm}$ sieve was examined in the field and the fine material was brought into the laboratory and examined there. The arthropod samples were picked with forceps and put in $75 \%$ ethanol. The O. surinamensis individual was identified originally by

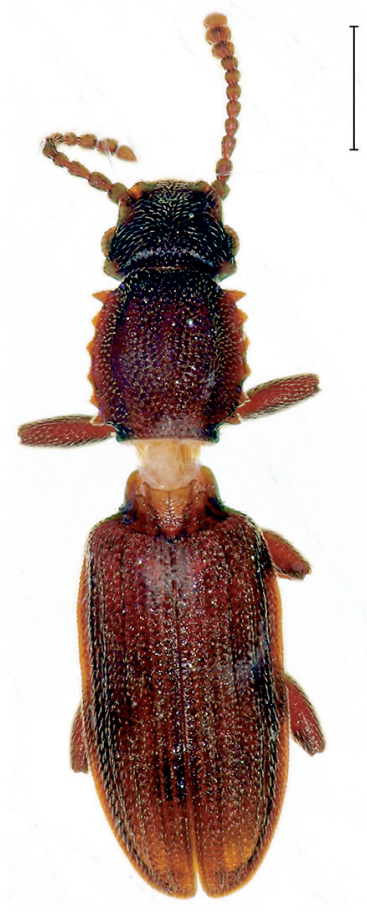

Fig. 1. Oryzaephilus surinamensis female found in a red wood ant (Formica rufa) nest. Scale bar: 0.5 $\mathrm{mm}$. Photo: E. J. Vesterinen.

comparing it with specimens in the Coleoptera collections of the Zoological Museum at the University of Turku (ZMUT), Finland. The sex was determined on the basis of the absence of spines on the basal part of the hind leg (Bousquet 1990).

\section{DNA barcoding}

Because the individual was found inside of a potentially hostile wood ant mound we wanted to verify the species also using the DNA barcode. Total DNA was extracted using a non-destructive method and QIAgen's DNEasy extraction kit (cat. number 69506; QIAGEN, Valencia, California, USA). The ethanol-stored sample was briefly dried at $60{ }^{\circ} \mathrm{C}$ and the whole specimen was then placed on $1.5 \mathrm{~mL}$ tube with extraction buffer. The sample was incubated overnight in the buffer at 55- $65^{\circ} \mathrm{C}$. After the incubation, the intact sample was removed from the buffer and placed in $99.5 \%$ ethanol to stop further digestion. After this, the extraction continued according to the extraction kits' protocol. The DNA barcode region (Cytochrome oxidase subunit I) was amplified and sequenced using universal animal primers LCO1490: 5'-GGG TCA ACA AAT CAT AAA GAT 
ATT GG-3' and HCO2198: 5'-TAA ACT TCA GGG TGA CCA AAA AAT CA-3' (Folmer et al. 1994).

Polymerase chain reaction (PCR) was carried out in $11 \mu \mathrm{l}$ reaction volumes containing $2 \mu \mathrm{l}$ of DNA extract, $5.75 \mu \mathrm{lddH} 2 \mathrm{O}, 1.0 \mu 110 \mathrm{x}$ buffer, $1.0 \mu \mathrm{MgCl} 2,0.5 \mu \mathrm{l}$ primerF (LCO), $0.5 \mu \mathrm{l}$ PrimerR (HCO), $0.2 \mu \mathrm{l}$ dNTPs, and $0.05 \mu \mathrm{l}$ BioTaq polymerase (Bioline). Thermal cycling was performed with the following program: $95^{\circ} \mathrm{C}$ for $5 \mathrm{~min}$, then $40 \mathrm{cycles}$ of $94^{\circ} \mathrm{C}$ for $30 \mathrm{sec}, 50^{\circ} \mathrm{C}$ for $30 \mathrm{sec}, 72^{\circ} \mathrm{C}$ for $1 \mathrm{~min} 30 \mathrm{sec}$, and a final extension period of $10 \mathrm{~min}$ at $72^{\circ} \mathrm{C}$. A blank water sample was used as a control in the PCR. The control sample was negative, indicating that there was no contamination during the PCR setup. The successful PCR product was purified and sequenced by Macrogen Inc. (South Korea). The sequence was trimmed using the software Geneious Pro 5.3.6 (Drummond et al. 2011) and then manually confirmed by eye. The total length of the trimmed high quality sequence was 635 base pairs. The resulting sequence was uploaded to the public Finnish Arthropoda Barcoding Project (FIART) project in the Barcode of Life Data System (Ratnasingham \& Hebert 2007) with process ID FIART001-11. The sequence was identified as Oryzaephilus surinamensis (100\% match) using BOLD Identification System. The trace files and pictures of the sample are also uploaded into the FIART project.

\section{Discussion}

The occurrence of $O$. surinamensis in the nest mound where it was discovered and other wood ant mounds needs to be further monitored. Formica rufa is a member of the mound-building red wood ant species (Formica rufa group) distributed over Eurasia and North America (Czechowski et al. 2002, Jurgensen et al. 2005). If the sawtoothed grain beetle can live in mounds of red wood ants, the mounds may become widespread sources for future infestations of this serious stored product pest.

Acknowledgements. We thank Tom Clayhills for confirming the morphological identification. In addition, we thank Niklas Wahlberg and two anonymous referees for comments on the manuscript. The study was funded by Emil
Aaltonen's Foundation (JS) and by Betty Väänänen's foundation (EJV). The permission to collect samples from Ruissalo was got from Centre for Economic Development, Transport and the Environment of South-West Finland (LOS-2006-L-291-259).

\section{References}

Bousquet, Y. 1990: Beetles associated with stored products in Canada: an identification guide. - Canada Department of Agriculture Publication 1837: 1-220.

Czechowski, W., Radchenko, A., \& Czechowska, W. 2002: The ants (Hymenoptera, Formicidae) of Poland. - Museum and Institute of Zoology PAS, Warsaw. $200 \mathrm{pp}$.

Drummond, A. J., Ashton, B., Buxton, S., Cheung, M., Cooper, A., Duran, C., Field, M., Heled, J., Kearse, M., Markowitz, S., Moir, R., Stones-Havas, S., Sturrock, S., Thierer, T. \& Wilson, A. 2011: Geneious v5.4. Available from http://www.geneious.com/.

Folmer, O., Black, M., Hoeh, W., Lutz, R. \& Vrijenhoek, R. 1994: DNA primers for amplification of mitochondrial cytochrome c oxidase subunit I from diverse metazoan invertebrates. - Molecular Marine Biology and Biotechnology 3:294-299.

Gilbert, M. T. P., Moore, W., Melchior, L. \& Worobey, M. 2007: DNA Extraction from Dry Museum Beetles without Conferring External Morphological Damage. - PLoS ONE 2: e272.

Halstead, D.G.H. 1980: A revision of the genus Oryzaephilus Ganglbauer, including descriptions of related genera (Coleoptera: Silvanidae). — Zoological Journal of the Linnean Society 69(4): 271-374.

Jurgensen, M. F., Storer, A. J. \& Risch, A. C. 2005: Red wood ants in North America. - Annales Zoologici Fennici 42: 235-242.

Laakso, J. \& Setälä, H. 1998: Composition and trophic structure of detrital food web in ant nest mounds of Formica aquilonia and in the surrounding forest soil. - Oikos 81: 266-278.

Päivinen, J., Ahlroth, P. \& Kaitala, V. 2002: Ant-associated beetles of Fennoscandia and Denmark. - Entomologica Fennica 13: 20-40.

Ratnasingham, S. \& Hebert, P. D. N. 2007: BOLD: The Barcode of Life Data System (www.barcodinglife.org). - Molecular Ecology Notes 7: 355-364.

Robinson, W. H. 2005: Handbook of urban insects and arachnids: A handbook of urban entomology. Cambridge University Press. 472 pp.

Rosengren, R., Fortelius, W., Lindström, K. \& Luther, A. 1987: Phenology and causation of nest heating and thermoregulation in red wood ants of the Formica rufa group studied in coniferous forest habitats in southern Finland. — Annales Zoologici Fennici 24: 147-155.

Sorvari, J. \& Hakkarainen, H. 2009: Forest clear-cutting causes small workers in the polydomous wood ant Formica aquilonia. - Annales Zoologici Fennici 46: $431-438$. 